\title{
Effect of Bibliotherapy on Unruly Behaviour of Young People in Correctional Homes in Lagos State Nigeria
}

\author{
Sophia Adeyeye and Fadekemi Oyewusi Ph.D. \\ University of Ibadan, Nigeria
}

\begin{abstract}
Bibliotherapy (use of books) is employed in this study with the intention to control the behaviour of young girls resident in a correctional home. This is relevant to the work of school librarians because they can help to find appropriate books that would influence positively the behaviour of young people in correctional homes. Thirty-six female participants took part in the bibliotherapy sessions that made use of Focus Group Discussion (FGD). These girls were separated into two categories - child offenders (17 girls) and out of parental control (19 girls). The study employed the use of a Nigerian authored story book which was read to them during the FGD for 10 weeks. The study found that after reading and discussion of themes in the book, the participants had more understanding of what good behaviour entailed. They became remorseful and sober which was evident during the discussions.
\end{abstract}

\section{Keywords: Bibliotherapy, Nigeria, Correctional Homes, Book Discussion}

\section{INTRODUCTION}

There has been growing concern in the Nigeria society regarding the increase in the unruly behaviour of young people (Adegoke, 2015). This informs stakeholders (librarians, scholars, parents/guardian, policy makers, teachers and others) resolve to continually discuss the worrisome dimension of unruly behaviour and its consequences on young people and the society at large. According to the last population census held in Nigeria in 2006, the population was 140,431,490 out of which age group 0-19 are 73,635,716 a fraction that is slightly high. These young people are faced with a number of challenges that could affect their abilities to live a healthy and normal life.

Preliminary investigations revealed that unruly behaviour that young people in Nigeria are involved in include being in possession of hard drugs, use of these drugs, cultism, bullying, truancy, rape, prostitution, examination malpractices and theft. All these wild behaviour are not only detrimental to physical and emotional wellness of the young people, it could also put the society into some problems (Muhammed, Salami, Adekeye, Ayinla and Adeoye, 2009). The involvement of these young people in unruly behaviour may likely make them behave in an unacceptable manner.

Bibliotherapy is a prescribed reading of books to ease a psychological illness. According to McCaffrey (2016), Bibliotherapy is commonly studied in psychology through focus group and it relies on controlled aspects and, more often than not, prescribed non-fiction self-help books that were created by a psychologist. However, personal testimonies of readers can show a powerful impact too, even though the results may not be from a controlled environment. This implies that books can help children and young people relate to and understand intricate feelings they may be going through. Bibliotherapy is an important programme that could be potentially developed into young people's activities in school libraries. The school librarian is assuming the role of a counselor (Oyewusi, 2016) where children and young people can be counseled through the recommendation of appropriate books that can assist them in removing their emotional burdens.

Bibliotherapy is using books and reading of appropriate books to correct and treat the person involved. It is systematic selection of reading materials which can be fiction or nonfiction books. It involves reading books like self help books, story books and poems in order to make young people feel better in themselves and about themselves in order to be able to cope with problems relevant to their situations and developmental needs at appropriate time. Bibliotherapy is of two types, the clinical bibliotherapy and developmental bibliotherapy (Ajayi, 2014). For the purpose of this study, 
developmental bibliotherapy was used. The developmental bibliotherapy is any planned use of books carried out with the aim to influence the personal growth and development. It is particularly relevant to the work of school libraries and school librarians.

Developmental bibliotherapy is practiced by school librarians to facilitate and help children and young people cope with issues or situations that could affect or has affected their behaviours. Careful selection of story books based on issues that the young people are going through is very paramount to having a good session/ therapy. The client will then be able to go through all the stages of bibliotherapy (identification, catharsis, insight and universalisation). According to Muhammed (2010) and McCulliss (2012), the future of any nation is largely determined by the well being and quality of its young people. Young people with emotional and behavioural problem are likely to be destructive, misbehave and have problem with coping with socially acceptable behaviour. Young people who have behaved unruly are more likely to commit crime which would take them to correctional homes. These sets of young people can still be helped through the proper use of intervention programmes like bibliotherapy. Thus, reading of prescribed and relevant books can bring back what has been lost in them and make these young people who have been incarcerated in correctional homes into better persons in the society. Bibliotherapy helps the juvenile in correctional homes in discovering, sharing and comparing issues in their lives and that of the character(s) in the book.

Most pupils are not aware that they can go to the library in order to get supportive literature that will help them with their problems and lead them to new knowledge, support, insight, and possible solutions (Baruchson-Arbib, 2010). She reiterated further that young people may not see the librarian as an appropriate person to go to for this kind of help; in addition, librarians hesitate to take on anything of a therapeutic nature, and rightly do so. Hence the need for the librarians in this study to take the bibliotherapy process to young people that has been classified as having unruly (wild and uncontrollable) behaviour and confined to correctional homes. The home used in this study have educational facilities with some form of library attached to them and had a focus group discussion using books as a form of correctional tool was used.

Correctional homes are institutions established for reformation and rehabilitation of persons assigned to it. Correctional homes in Nigeria for young people are referred to as remand homes under the Child and Young Persons Law (Ajayi, 1997; Child and Young Persons Law of Lagos State, 2003; Alemika and Chukwuma 2005;). Correctional homes in Nigeria serves as detention sites for young people who has violated the young people and young person's law or the criminal code (young people in conflict with the law), young people in need of care and protection and beyond parental control. The homes were established with the purpose of reformation, rehabilitation and re integration of such remanded young people back to the society. These set of young people were remanded because of their involvement in unruly behaviour, there is need to properly rehabilitate them so that the purpose of remanding them in correctional homes will not be defeated. Rehabilitation is a necessary resource that is provided to young people (Darbouze, 2010).

Therefore, young people in correctional homes are counseled, educated, rehabilitate, reformed using different interventions in order to empower them to develop skills that could help them to go through life and keep them out of trouble (Bella, Atilola and Omigbodun, 2010). There are different intervention programmes that could be used to help in rehabilitating the remanded young people. According to Ojo (2012), there are several ways of helping young people in coping with issues that face them. For the societal peace and tranquility, there is need to introduce and implement an intervention programme which will be of help to the young people by helping to change them into better persons and re integrate them back to the society. One of the several options available is bibliotherapy.

\section{Role of School Libraries in Changing Behaviours among Young People}

School Librarians and libraries can help young people with reading activities to empower and emancipate them from actions that are detrimental both to them and the society. Through reading, young people could enter into the life and experiences of others and this could have implication on their knowledge, scope of experiment, enjoyment and long lasting solution to what they are passing through. A well written story book or novel has other uses aside from educational purpose; it could provide 
information that is new to the reader, meet recreational and entertainment needs and also help to gain insight into the issues that the young people are dealing with. Reading of books have been an instrument of change, development and helps in effective decision making (Akinola, 2014).

During reading, users of books are able to compare and contrast behaviour/characters in the book and this will help the reader with inferring some form of reasoning. The role of the librarian as leader of bibliotherapy group meetings is an effective one in situations involving inmates in correctional institutions. In addition to motivating reading interests and helping to escape for a time from his problems, bibliotherapy groups have other important goals such as socialization and communication (Hannigan, 1962 ). In Nigeria, the most convenient place for young people to have access to books is the library, preliminary observations has revealed that the economic recession in the country would not allow many young people the opportunity to buy personal books for themselves in the face of other pressing needs like food, clothing and shelter. But, a major question to ask is whether the libraries themselves are equipped. Literature (Adegoke, 2015) has shown that several school libraries in Nigeria are not equipped with timely and adequate resources.

School libraries are one of the sources for providing reading resources and a gateway to knowledge. It is a repository of books and other resources that could help young people shape their thoughts and influence their actions. However, we observed that most correctional homes in Nigeria do not have functional libraries where young people could go to read for pleasure. Some of them have a semblance of a library but not a library as defined in the IFLA 2015 School Library Guidelines. The IFLA School Library guidelines (2015) reveals that a school library provides a range of learning opportunities for individuals, small groups, and large groups with a focus on intellectual content, information literacy, and cultural and social development. According to IFLA/UNESCO School Library Manifesto (1999), the school library provides information and ideas that are fundamental to functioning successfully in today's information and knowledge-based society. Unruly young people need the school library to help with their cultural and social development by transforming them into responsible citizens. This is because they are housed in correctional homes and the IFLA/UNESCO School Library Manifesto (1999) also reiterated that specific services and materials must be provided for those who are unable to use mainstream library services and materials. Young people in correctional homes will enjoy the benefits of access to the schools which can assist transform them the following ways:

- School librarians motivate students to discover the world through reading. This is because they help students to locate books and information on the topics of their interest.

- School library services with good resources will help young people explore the world around them through print and electronic media (Oyewusi, 2016).

- According to Igbokwe, Obidike and Ezeji (2012), good library services should include availability of rich and good resources in stimulating environment that will help in attaining the correctional objectives of reformation and rehabilitation of the young people in the correctional homes.

- A functional library would not only provide textbooks for curriculum needs of the young people, but also provide books that will enhance skills that could help the young people in the future.

- The school library equips students with life-long learning skills and develops the imagination enabling them to live as responsible citizens. It plays this role by selecting, acquiring and providing access to appropriate sources of information (Mahajan, 2010).

Appropriately shared stories provide opportunities for young people to gain insight and learn healthier ways to face difficulties. Young people's literature is a therapeutic tool for facilitating emotional growth and healing. Stories provide a catalyst for change, providing young people with other perspectives and options for thoughts, feelings and behaviours (Okwilagwe and Mubonyi, 2011). School librarian has the responsibility to bring books and young people together for therapeutic reasons in bibliotherapy. According to Hannigan (1962), bibliotherapy can serve group therapy by expertly providing material for discussion and also by reinforcing and complementing the discussion through appropriate reading lists. The librarian, in turn, acts as an analyzer of the discussion material and provides the medicament, so to speak, for the use of the group therapists. According to her, the school librarian with his knowledge of 
books and the psychiatrist with his knowledge of people generally and of his patients particularly, make an excellent team.

In carrying out the function of bibliotherapy the librarian recommends and provides reading material through (a) readers' advisory service, (b) individual and/or group therapy, and (c) special library activities correlated with patients' interests (Hannigan, 1962)

- Readers' Advisory Service: The librarian stimulates and develops reading interest by recommending and providing reading materials through discussions with young people who come to the library. The librarian assists patients with book selection, and makes suggestions based on their requests, needs, reading habits, physical condition, and educational, social and occupational and language background.

- Individual and Group Therapy: The objective of individual and group therapy is to lessen the mental and emotional strain and to motivate the patient toward normal living through professional guidance in the use of library materials.

- Special Activities: The librarian aids the patients' physical and mental recovery and adjustment by creating and stimulating their initiative, self-reliance, and confidence through projects leading to the use of library material. Hobby and vocational displays, nature study groups, library activities for special occasions, etc., correlated with the vocational, recreational, and cultural background of the patients, are organized and developed by the librarian to encourage the use of the library in connection with these projects.

It is therefore, imperative for libraries and librarians to render specialised services to targeted groups or disadvantaged group like young people in correctional homes. This is because books read in these specialised libraries can affect a young person's feelings and actions. Correctional homes with library services like other institutions of the society could help in reformation and re integration of the incarcerated young people back into the society just as it will also help the young people in correctional homes to imbibe reading habit.

\section{STATEMENT OF THE STUDY}

Young people in correctional homes need urgent attention in the area of unruly behaviour. It is one of the major reasons why they are being incarcerated in correctional homes. When these juvenile are not properly remediated, it can led to more criminals being released into the society. This could create more serious problem for the society at large. The reformatory roles of correctional homes in the country have been neglected over a long period of time with several homes without reading facilities provided for the young people. This could lead to involvement in more disobedient behaviour among inmates. All this are likely to have negative effect on security and gradually cumulate into youth restiveness and insurgency like Boko Haram as seen in the northern of the country.

\section{METHODOLOGY}

Purposive sampling procedure was used to select participants for the Focus Group Discussion (FGD). The participants are delinquent young people in Girls Correctional Home in Idi-Araba, Lagos State. Total population of girls in the correctional home is 70 girls. They belonged to four categories: 16 young girls in need of care and protection, 19 girls who are beyond control, 17 girls who are child offenders and 19 girls who needed shelter. The participants in the focus group discussion included 36 girls in two groups who are in the categories of child offenders (17 girls) and out of parental control categories (19 girls). The main purpose of the focus group discussion is to provide the bibliotherapy procedure and discussion using the book "My storybook on values for the African child" by Omoegun (2014). FGD also helped in soliciting in-depth information on the solutions to the issues facing the young girls in the correctional home using the story from the book as a baseline for bibliotherapy treatment.

\section{RESULTS AND DISCUSSION}


The project was focused on young people in correctional homes in Lagos state, Nigeria. These young people exhibited unruly behaviour like pretty theft, drug and substance abuse, prostitution, truancy, armed robbery, arson, man slaughter and so on. These sets of young people were alleged to have committed the listed offences and they were taken into the protection care of the homes. Firstly, the researchers held a joint meeting with the correctional homes management and teachers to help in creating an atmosphere for reading and understanding.

\section{Procedure during FGD}

The story book "My Storybook on Values for the African Child" by Omoegun (2014) was distributed to all the girls for independent reading for one week which was followed by eight weeks of group discussions and activities while the tenth week was used as a wrap up session.

The bibliotherapy process lasted for ten weeks; it was observed that the girls got into the correctional homes after they were involved with unruly behaviour ranging from pretty theft, drug and substance abuse, prostitution, truancy, armed robbery, arson, manslaughter and so on. The procedure followed during this study is as follows:

Session One:

Introduction by the researcher for the purpose of gathering;

- The book was introduced and

- Books were given to the young girls for independent reading.

Session Two:

- Guided reading from the story book which was based on the theme "Cooperation". Session Three:

- This included activities (questions and discussion) on the theme "Cooperation". Session Four:

- Guided reading from the story book with the theme " Honesty". Session Five:

- Questions and discussions on theme "honesty".

Session Six:

- Guided reading from the story book on the theme "Responsibility".

\section{Session Seven:}

- Questions and discussions activities on theme "Responsibility".

Session Eight:

- Guided reading from the story book on the theme "Tolerance".

Session Nine:

- Questions and discussions activities on theme "Tolerance".

Session Ten:

- Wrap up session which included appreciation of participants.

After systematic reading and getting involved in the activities that follows which reading, it was observed that majority of the young people in the child offenders and out of parental control categories wished they were not involved in the unruly behaviour that brought them to the correctional home and promised to be of good conduct whenever they are released to the society.

The materials used for the Focus Group Discussion included:

- Notepads and Pencils

- Focus Group Script

- Tape Recorder from the mobile phone (picture session was not allowed in the home)

- Ethical Consent Forms was received from Lagos State Ministry of Women, Youth, Social Welfare and Development in charge of the home.

- Clock for Start on-time and end on-time.

- Refreshments to make the young people feel comfortable

Focus Group Discussion 
The stories in the book are designed to motivate young people and get them involved in thinking positively about themselves, others and the world around them in relevant ways. The stories include themes that could help young people to develop personal, social, peaceful, cooperative and emotional values. The stories in this book are also based on core living values. Each story ends with some activities that were used during the FGD to make the participants reflect, imagine, communicate, create, write, artistically express and play with values.

Theme 1 : Cooperation

In the book, cooperation was discussed in the story to show that cooperation is necessary in the community, at home, school etc to have a better living community.

Five responses from the participants during the interactions after reading the book would be reported verbatim as follows:

1. How can you show cooperation in your class and home?

Respondent One: By talking with one another from time to time;

Respondent Two: Listening to other people views;

Respondent Three: Keeping to lay down rules and regulations and respecting people in authority;

Respondent Four: Reporting those that are disobedient to people in authority

Respondent Five: Respecting other people view

2 . What can you do to get others to cooperate with you?

Respondent One: Allowing them to speak out their minds

Respondent Two: By not being proud or full of myself

Respondent Three: Allowing other people to participate in activities

Respondent Four: I should be willing to learn from others

Respondent Five: Allowing others to express themselves

Theme Two: Honesty

In the book honesty was shown in the story when one of the characters, a poor man helped the king to recover his stolen golden cup from one of the king's servant that stole it. He was rewarded and other bad characters were sent to the prison. The young people were led to discuss honesty by discussing the following questions.

Activities 1: Tell me some things about yourself

Respondent One: I am a 14 years old girl. I got caught while trying to break into a shop and was in possession of a harmful and dangerous weapon. This is not my first time. I don't have reasons to steal. My daddy is well read and tried everything within his means to bring me up properly but I was influenced by bad friends. I am ashamed and will not steal again

Respondent Two: My parents were divorced and my step mother was maltreating me. I ran away from home to the motor park, where I got involved in bad actions. I came into the correctional home when I was 14 years old and I am now 17 years.

Respondent Three: I am a 16 years old girl. I was raped when I was 6 years by an unknown person while waiting for my parents in our rented one room apartment. Since then I got annoyed and angry with everybody around me. I became disobedient to annoy people around me especially my parents because I feel they didn't protect me enough. I got here because I stabbed another girl.

Respondent Four: I am a 15 years old girl and I ran away from home to Lagos State because my mother is a prostitute. I slept under the bridge and learnt so many vices from there. I was taught to smoke hemp and other harmful drugs. I got to the correctional home when I got caught with dangerous weapon and illicit drugs by government officials.

Respondent Five: I am 14 years old girl and all attempts by my parents to keep me in school failed. I skipped school and classes. My mother later took me to a boarding house. I escaped and after three months of searching, she brought me here as a child out of parental control.

Activity 2: Were you honest with the information you gave about yourself

Respondent One: Yes

Respondent Two: Yes

Respondent Three: Yes 
Respondent Four: Yes

Respondent Five: Yes

Theme Three: Responsibility

The following discussion ensued when the question was asked on responsibility.

Activity 1: What are you to do as a responsible child every day?

Respondent One: Help with house chores and take responsibility for my actions.

Respondent Two: Learn to accept my mistake and face the consequences.

Respondent Three: Love my fellow human being and obey people in authority.

Respondent Four : Respect the law of the land and people in position of authority.

Respondent Five: Be punctual in school and not to skip classes.

Activity 2: Who do you blame when you make a mistake and why?

Respondent One: Myself, because I'm learning to take responsibility for my actions.

Respondent Two: People around me. No particular reason I feel I should just blame them.

Respondent Three: My mother because she is supposes to take care of me.

Respondent Four: Myself. I'm fully responsible for my action.

Respondent Five: My friends. They influenced my behaviour.

Theme Four: Tolerance

The book discussed tolerance by revealing that one of the characters in the story did not tolerate the other person which led to her destruction. Few of the young people's responses are as follows:

Activities 1: Write three things you can do to show tolerance

Respondent One: Letting go of wrong doings by other people, not nagging and allowing others to express their views.

Respondent Two: Show love to others, be patient and don't feel superior to others.

Respondent Three: Listen attentively to others, adapt to situation around you and don't have negative views about others.

Respondent Four: Being patient with other people around.

Respondent Five: Don't hold on to other people's mistake, don't get irritated easily and allow other people's view on issues.

Activity 2 : How you can work with the girl or boy who nobody else wants to work with in your class?

Respondent One: Allow him or her to air their views.

Respondent Two: Show love.

Respondent Three: Be patient with him or her.

Respondent Four: Allow him or her to prove himself or herself.

Respondent Five: Respect individual decisions.

The researchers noticed that while the stories were being read the young people were anxious, but during the discussion period it was also discovered that the participants maintained eye contact with the researchers. This was not the case at the beginning; they later assumed a sober look and some of them cried. The story had an emotional effect on them.

\section{CONCLUSION AND RECOMMENDATION}

The following conclusion could be drawn from the interactions during discussion with the young people in the correctional homes. Through system reading, the girls were able to see that they are not alone and that several other young people were also passing through or have passed through whatever they are experiencing. Those issues can also be overcome like the characters in the story book read during bibliotherapy. The bibliotherapy intervention by the researchers (librarians) has created awareness that reading story books can help them to learn from the experience of other young people.

Young people were able to make informed decisions to guide them in behaving in healthy way that is not harmful and take responsibility for their actions. The use of bibliotherapy as intervention to help unruly young people in correctional homes has proved that libraries in correctional homes in Nigeria can help create space and place that will meet the needs of these young people emotionally. It has 
demonstrated that an effective library within the correctional home could help the young people to refocus and create a safe environment.

The primary function of the librarian on the therapy team, as in other areas of library service, is based upon cognizance of the needs of the community and of individual reader and upon knowledge of books available to meet those needs. Therefore, school libraries should be an important institution in the implementation of bibliotherapy, and the task of a school librarian in this process should be to help each individual child to find "his book". Department of Library Studies in universities should introduce courses in their curriculum (where absent) that will help produce librarians who are "interested and competent" in this important field. This is because school librarians need to know the purposes and objectives of having constant bibliotherapy sessions with students in need of such interventions so that they don't end up committing crimes that would led them to correctional homes.

\section{REFERENCES}

Adegoke, N. (2015). Factors responsible for juvenile delinquency in Nigeria. A case study of selected primary schools in Ikorodu, Lagos State, Nigeria. Research on Humanities and Social Science, 5(5). Retrieved April 29, 2016 from http://www.iiste.org

Ajayi, N. A. (1997). Bibliotherapy in health care delivery in Nigeria. Journal of Physical Education and Research, 3, 442-446

Akinola, A. N. (2014). Bibliotherapy as an Alternative Approach to Young people's emotional Disorders : Creative Reflections. 5 :1281-1285. Retrieved May 17, 2016 from http://dx.doi.org/10.4236/ce.2014.514146

Alemika, E. E. O., \& Chukwuma, I. C. (2005). Juvenile Justice Administration in Nigeria: Philosophy and Practise. CLEEN Publisher. Ikeja.

Baruchson-Arbib, S., (2000). Bibliotherapy in school libraries; An Israeli experiment. School Libraries Worldwide, 6(2), 102-110.

Bella, T.T., Atilola, O., \& Omigbodun O. O. (June, 2010). Young people within the juvenile justice system in Nigeria: Psychopathology and Psychosocial needs. Annals of Ibadan Postgraduate Medical, 8(1).

Child and Young Persons Law of Lagos State. (2003). Lagos: Ministry of Justice, 2(3, part 5), 33.2:

Darbouze, K. (2010). Rehabiltative methods and the effect on juvenile delinquents. College Park, Maryland: University of Maryland.

Igbokwe, J.C., Obidike, N.A. \& Ezeji, E.C. (2012). Influence of electronic media on reading ability of school children. Library Philosophy and Practice. Retrieved December 23, 2016, from http://unllib.unl.edu/lpp

International Federation of Library Associations and Institutions (2015). IFLA School Library Guidelines (2nd rev. ed.). The Hague, Netherland: IFLA.

IFLA/ UNESCO. (1999). School Library Manifesto. The Hague, Netherland: IFLA.

Lehmam, V. (2005). Prison Library: A vital line to Education, Rehabilitation and Recreation. Education Libraries, 24(1), 5-10.

Mahajan, P. (2010) School Libraries in India: Present-day Scenario. Library Philosophy and Practice. Retrieved March 3, 2017 from http://www.webpages.uidaho.edu/ mbolin/mahajan5.htm

McCaffrey, K. (2016). Bibliotherapy: how public libraries can support their communities' mental health. Dalhousie Journal of Interdisciplinary Management. Retrieved March 3, 2017 from http://dx.doi.org/10.5931/djim.v12i1.6452

McCulliss, D. (2012). Bibliotherapy: Historical and research perspectives. The interdisciplinary Journal of Practice, Theory, Research and Education, 25(1), 23-38.

Muahammed, A., Salawu B, Adekeye D, Ayinla S and Adeoye, V.N. (2009).The nexus between family instability and youth crime: Evidence from Nigeria. International Journal of Human Development and information system, 2(2), 41-53.

Ojo, D.O. Maltias. (2012). A sociological review of issues on juvenile delinquency. The Journal of International Social Research, 5(21), 468-482. 
Okwilagwe, O.A. and Mubonyin, M.V. (2011). The role of bibliotherapy in value system formation by undergraduates in the university of Ibadan, Nigeria. US-China Education Review. (A2) 240- 250

Omoegun, M. (2014) My storybook on values for the African child. Lagos, Nigeria: Litramed

Oyewusi, F. O. (2016). Understanding School Library Media Concepts. Ibadan, Nigeria: Stirling-Holden Publishers.

Hannigan, M. (1962). The librarian in bibliotherapy: Pharmacist or bibliotherapist? 11(2), 184-198.

Library Trends, 